\title{
Common Legislation Regarding Discharge of Sewage and Ballast Water by Ships in the Caspian Basin
}

\author{
Sarvar Khalikov¹,2, Altynbek Smailkhan', Margulan Dairshenov³, Mahdi Birafane ${ }^{1}$ \\ ${ }^{1}$ College of Transport \& Communications, Shanghai Maritime University, Shanghai, China \\ ${ }^{2}$ Uzbek State University of World Languages, Tashkent, Uzbekistan \\ ${ }^{3}$ Kazakhstan Maritime Academy, Kazakh-British Technical University, Almaty, Kazakhstan \\ Email: kh.sarvar@bk.ru,smailkhan.a@gmail.com, dairshenov@gmail.com, mahdi.birafane@hotmail.com
}

How to cite this paper: Khalikov, S., Smailkhan, A., Dairshenov, M., \& Birafane, M. (2020). Common Legislation Regarding Discharge of Sewage and Ballast Water by Ships in the Caspian Basin. Journal of Geoscience and Environment Protection, 8, 65-75. https://doi.org/10.4236/gep.2020.82005

Received: January 9, 2020

Accepted: February 8, 2020

Published: February 11, 2020

Copyright $\odot 2020$ by author(s) and Scientific Research Publishing Inc. This work is licensed under the Creative Commons Attribution International License (CC BY 4.0).

http://creativecommons.org/licenses/by/4.0/

\begin{abstract}
The Caspian basin for a long time did not have a legal status, so the question of the division of the seabed was in question. In addition, international conventions such as MARPOL, UNCLOS, BWM did not have jurisdiction over Caspian waters. Due to the lack of general rules regarding the Caspian basin, the risk of pollution from ballast water and sewage discharges remains relevant due to the active shipping industry. But on August 12, 2018, the leaders of littoral states signed the Convention on the Legal Status of the Caspian Sea, although the situation remains complicated. Thus, in the manuscript the authors provide the first insight into the issues of sewage and ballast water in the Caspian, and the role of oil and natural gas in the regional development.
\end{abstract}

\section{Keywords}

Volga-Don Canal, The BWM Convention, Tehran Convention, UNCLOS, Caspian Littoral States, Caspian Summit

\section{Introduction}

Shipping is the cheapest way to carry the cargo. Over the centuries, this transport mode has developed well due to increased demand. Cargo is being transported around the whole world by sea, oceans, lakes, reservoirs, and rivers. It touches even hard-to-reach places such as the Caspian basin. The Caspian is a closed water reservoir and a natural border for five countries: Azerbaijan, Kazakhstan, Iran, Turkmenistan and the Russian Federation.

The Caspian contains about half as much salt as in ocean water, and secondly, due to its remote geographical position, the bio-system there is different and 
sensitive. Thus, such a unique marine environment of the Caspian Sea has fewer opportunities for recovery from threats posed by people, and the current marine industry continues to have a negative impact on the environment, namely invasive species transported in ballast water and sewage discharge. But before enacting any law in order to minimize pollution of the sea caused by the above two problems, the littoral states must give the basin a legal status.

The Caspian has only one indirect passage into the ocean through the Volga-Don Canal of the Russian Federation, therefore it can be considered as a lake. But there is no such thing as a lake with the seabed of the oceanic crust. The Caspian's southern half is oceanic, and only the northern half actually has a continental basin. Since its basin is partially oceanic and its water is adequately salty, the Caspian should be officially considered a sea.

The meetings of the littoral states can last forever on the matter in question, as since the collapse of the Soviet Union, each country's pursuit of "a fat piece of cake" in the Caspian basin is due to the presence of rich oil and natural gas reserves. Figure 1 below provides the data only about the explored reserves.

Based upon the information mentioned above, the goal of this research is to understand if the common legal set of regulations regarding discharge of ballast water and sewage into the Caspian will be issued even after the Convention on the Legal Status of the Caspian Sea. To come up with the main research objective, some aspects need to be explained further in the manuscript and namely, the first insight into the issues of ballast water (Section 2) and sewage (Section 3 ); oil and natural gas reserves, which was and remains the main problem for determining the legal status in the Caspian (Section 4).

\section{Ballast Water}

For safe navigation on a ship it is necessary to comply with the rules related to the safety of the marine industry. One of these standards is draft, and draft depends on the weight of the vessel. Draft of ships sometimes creates problems for the ships themselves. Draft can only be changed by changing the weight of the vessel, that's why there is ballast water on board. The draft must be less at the shallow waters in order to keep under keel clearance safe for the voyage. So, it is easy to understand that all ships which came to the Caspian had performed the ballast discharge and inlet of ballast waters from the places where they have been traveled. In other words, a ship takes water from another sea and throws it into the Caspian. Thus, the use of ballast water directly causes the movement of bio-organisms. These bio-organisms can be bacteria, germs, small invertebrates, eggs, cysts and larvae of various species. Taking into account the uniqueness of the flora of certain regions, some new invasive organisms can cause a sufficient danger to the environment of the Caspian basin. Invasions can damage the environment, human health, property and resources.

\subsection{Invasive Species}

U.S. Environmental Protection Agency (2019) says that the spread of invasive 


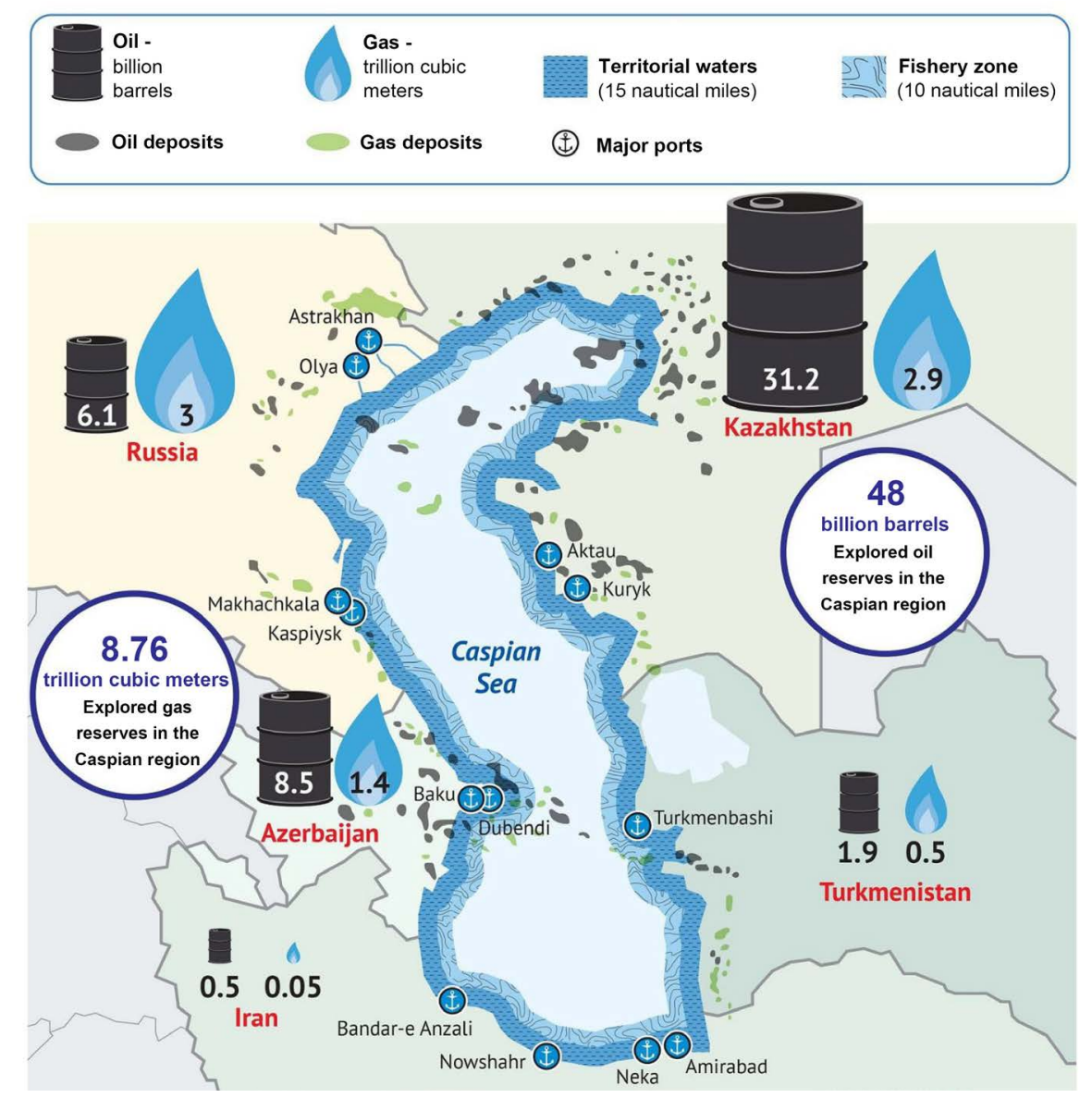

Figure 1. Oil and gas reserves in the Caspian region (Source: Valdai Club Foundation, 2018).

species is now perceived as one of the most dangerous to the biological and economic well-being of the planet. The first study of the characteristics of alien species was in 1903 when scientists discovered the massive distribution of Asian algae of the phytoplankton Odontella in the North Sea (Fonseca de Souza Rolim, 2009). Another striking example of invasion is the Great Lakes of America, which have 160 known invasive species, half of which have only been introduced since 1960 (Patton, 2006). In the case of the Caspian, the invasion started with the jellyfish Mnemiopsis leidyi (Figure 2).

\subsection{Mnemiopsis Leidyi}

The motherland of Mnemiopsis is United States' Atlantic beaches. The large estuarine Western Atlantic ctenophore could already damage the floras of Black and Azov Seas by hunting fish eggs and fish larvae and in addition, on the day it can devour ten times more than its own weight (Ivanov et al., 2000; Kremer, 1979), thus feed base for kilka in these two seas began to deplete. The cost of damage to the fishing industry in the Black basin caused by the invasion of Mnemiopsis is estimated at $\$ 250$ million, "and anchovy fisheries in the Sea of Azov have collapsed" (Patton, 2006). 


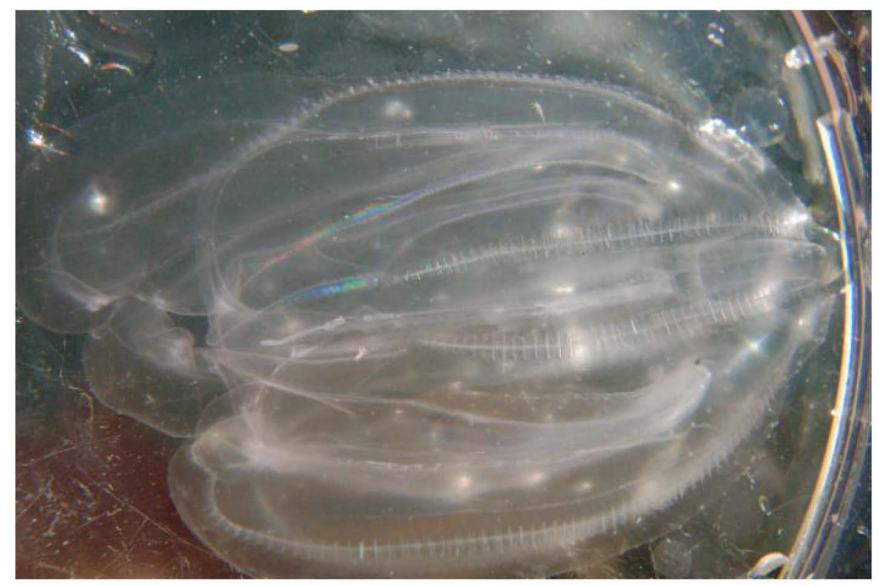

Figure 2. The shape of Mnemiopsis leidyi (Source: De Blauwe, 2010).

In the Caspian, this type of jellyfish was first recorded in 1996 by Turkmen fishermen, and three years later its presence was confirmed by scientific survey (Harkonen et al., 2012; Ivanov et al., 2000). Such a factor as survival for several weeks without food made it possible for Mnemiopsis to be transported in the ballast waters of ships from the Sea of Azov to the Caspian Sea via the Volga-Don Canal.

Unfortunately, as soon as Mnemiopsis entered the Caspian basin, it also affected almost all levels of organization of living in the sea: 1) Negative effect on the anchovy tyulka; 2) through consumption of meroplankton, ctenophore influenced roach, bream, common carp, sturgeon and stellate sturgeon; 3) the sharp reduction in the number of Caspian kilka led to the unsatisfactory feeding of the Caspian seal and was one of the reasons for the delay in its post-feeding migrations to the North Caspian (Kamakin et al., 2018). Invasive species caused by ballast water can continue to terrorize living organisms in the region and in the whole world if special measures are not taken.

\subsection{Article 196 of the United Nations Convention on the Law of the Sea (UNCLOS)}

As the aforementioned issue of ballast water is considered the international problem, the UN mentioned its importance in the article 196 of the UNCLOS:

\section{"Article 196}

Use of technologies or introduction of alien or new species

1) States shall take all measures necessary to prevent, reduce and control pollution of the marine environment resulting from the use of technologies under their jurisdiction or control, or the intentional or accidental introduction of species, alien or new, to a particular part of the marine environment, which may cause significant and harmful changes thereto.

2) This article does not affect the application of this Convention regarding the prevention, reduction and control of pollution of the marine environment."

Despite the information above, the UNCLOS rules cannot come to power because landlocked countries in the Caspian region, such as Turkmenistan and 
Kazakhstan, and neither signed nor ratified the convention (Chesterman et al., 2019). In the case of Iran, this is one of the four Asian coastal countries that signed the convention but did not ratify it. The second reason was the legal status of the Caspian if it is a high sea or not, in addition, UNCLOS did not have a clear definition for the phrase "high sea" (Zimnitskaya \& von Geldern, 2011).

\subsection{Ballast Water Management Convention}

The most powerful tool on this ballast water issue is the Ballast Water Management Convention (BWM Convention), which was adopted by consensus at a diplomatic conference held at IMO headquarters in London on February 13, 2004. And it entered into force on September 8, 2017.

The BWM sets some rules, the standards of which must be respected by all vessels. The standards cover ballast water management on board for all vessels in accordance with the draft precipitation management plan. However, all vessels must have a record book and ballast water certificate. They also need to follow ballast water management procedures in accordance with a given standard. As a solution, ships need to exchange water in ballast tanks. And finally, most vessels need to install a ballast water treatment system on board. When it comes to ballast performance standard, the BWM Convention has more precise requirements (Ballast Water Conference, 2004):

"Regulation D-2 Ballast Water Performance Standard-Ships conducting ballast water management shall discharge less than 10 viable organisms per cubic metre greater than or equal to 50 micrometres in minimum dimension and less than 10 viable organisms per milliliter less than 50 micrometres in minimum dimension and greater than or equal to 10 micrometres in minimum dimension; and discharge of the indicator microbes shall not exceed the specified concentrations."

The aforementioned regulation applies to those waters, which Parties ratified the BWM Convention. In the Caspian, the situation is not fully common, because only two countries out of five ratified it: Russia and Iran. Thus, the BWM needs to be followed by the states of the Parties, and by the vessels, sailing on the waters of the Parties. However, there is another previously mentioned point to pay attention, which is the unclear legal status of the Caspian basin. The BWM Convention has a force only in international waters. The reason why Iran and Russia ratified this is that they both are having an access to international waters.

\section{Sewage}

The discharge of untreated wastewater into the sea is considered one of the most serious marine pollution, since it can pose a risk to human health and bio-organisms as a result of oxygen depletion. Sewage is that risky, as it may contain pathogenic bacteria, microbes such as Giardiasis, Amoebic dysentery and cholera. Pathogens can also be included in fish, which is considered seafood for humans. Sick fish annually poison a myriad of people around the world. Usually, agencies close the fishery when contamination is detected. Thus, wastewater can lead to both eco- 
nomic losses and the base of the fishing industry. All this means that the presence of wastewater is not only harmful to the ecosystem and creates a danger to human health, but also interferes with fishing and tourism. When it comes to the tourism industry, sewage can also damage the visual sights of the beaches.

\subsection{Salinity in the Caspian}

Discharge of wastewater into freshwater basins can have a more dangerous result than discharge into the oceans, as the salinity plays the main role in this case. Yang et al. (2015) prove that salt water has more ability to reduce the damage of sewage. Two representatives of marine organisms were taken for research: a marine polychaete worm and the alga Tetraselmis marina. At the end of the research, the scientists concluded that the effluent of chlorinated saline was less acutely toxic to organisms than its freshwater counterpart. This, even more, underlines the problem of the harmful effects of wastewater in the Caspian Sea. The salinity in the Caspian is twice less than in the World Ocean indicates that the Caspian basin has a lower ability to withstand wastewater. The Caspian littoral states strive to achieve zero tolerance for any discharges into the sea, which means that all ships must deliver waste to port facilities or to specialized carriers. However, the discharge of sewage water into the sea exists and the figures below prove that.

\subsection{Sewage Discharge in the Caspian. The Case of "Kazmortransflot"}

The total volume of tanks of sewage on board certain vessels in the Caspian basin is not sufficient to store all waste for the whole voyage, an example is the "Oral" oil tanker of the Kazakh national maritime shipping company "Kazmortransflot (KMTF)". According to the official specifications of the tanker, the volume of wastewater tank is 16.65 cubic meters. The tank is suitable for both sewage and sanitary wastewater. And the tank overflow alarm is triggered by $80 \%$ of the level, which means that in this case the alarm should empty the tank, otherwise it will be full. According to the sanitary rules, the standard amount of wastewater per person for one day for a sea vessel is 200 liters. The total number of crew members is 30 .

Analyzing the above information, it is clear that the amount of wastewater in one day can be up to 6 cubic meters. The total volume is 16.65 cubic meters. Thus, it can be completely filled in 2775 days. But it will reach $80 \%$ of the volume (13.32 cubic meters) in 2.22 days. The average time required to complete one separate trip from port to platform and back to port is about 4 days. Most of the vessels stand at the "Korchagin" oil field of the Caspian basin, which is located in the middle of the sea and the ships wait in line to load crude oil. This is the reason why the journey lasts four days. Thus, it is physically impossible to store all wastewater inside the tank during the entire trip, this proves the fact of wastewater discharge into the sea. KMTF has six similar tankers in the Caspian. However, the representative of the company, Ms. Karlygash Orynbekovna Kop- 
baeva, argues that KMTF declares zero tolerance towards wastewater discharges into the sea.

It shouldn't be forgotten that sea pollution by sewage occurs not only in the Caspian region, but throughout the world. And if IMO's BWM Convention was issued to solve problems caused by ballast water, then Annex IV of the International Convention for the Prevention of Pollution from Ships (MARPOL) was a solution to prohibit the discharge of raw sewage (Julian, 2000; Khalikov et al., 2020).

\subsection{Marpol, Annex IV}

MARPOL, Annex IV, establishes rules for discharging wastewater into the ocean from ships, including rules for equipment on board and systems that control wastewater discharges, the provisions of port facilities for wastewater reception; and requirements for certificates and examinations. The main requirement is the prohibition of wastewater discharge at a certain distance from the nearest shore and namely, 12 nautical miles from land. Annex IV was ratified by all Caspian littoral states, but its requirements are not followed in the Caspian water, as the Caspian is not considered high sea. As in Section 2, the legal status of the Caspian Sea has become an obstacle to solving the problem of sewage.

\section{Activities over the Legal Status of the Caspian Sea}

After the collapse of the Soviet Union, the division of the Caspian basin became a hot issue for the newly independent countries, and each country wanted to maximize the benefits of the Caspian bottom. In the middle of 90s, the Caspian northern countries understood the importance of the basin because, despite the unresolved problems, the international investments increased at that time. The best example is the "Contract of the Century" signed in Baku in 1994, which included $80 \%$ of investments by foreign companies (Nasirov, 2010). This contract pushed Russia to realize the need for separation of the seabed, and by the end of 1998 the Russian Federation, Kazakhstan and Azerbaijan came to the solution of the problem of segregation of the seabed. These three countries established the boundaries of the shelf among themselves. However, other countries do not have the same agreements that also attach importance to legal status. So, the littoral states arranged "Caspian Sea Summits" altogether in 2002, 2007, 2010 and 2014 in order to solve this question.

During the summits, the officials couldn't ignore the importance to keep the Caspian safe and clean. In each session, main questions regarding the pollution, collaborations, legal status, open questions were discussed. The best solution what they found became the Tehran Convention (Table 1), which entered into the force in 2006. It is the first common framework convention for the protection of the marine environment in the Caspian basin.

The uniqueness of the document is not in having the specific legislation and rules. For instance, the general obligations of this legal agreement say all parties need individually or jointly take all appropriate measures to prevent, reduce and control 
Table 1. Conference of the parties and protocols to the Tehran convention.

\begin{tabular}{|c|c|c|c|c|c|}
\hline Number & The name of Protocol & City & Country & Date & Ratified by \\
\hline CoP 1 & & Baku & Azerbaijan & May 2007 & \\
\hline $\mathrm{CoP} 2$ & & Tehran & Iran & November 2008 & \\
\hline $\mathrm{CoP} 3$ & $\begin{array}{l}\text { The Protocol Concerning Regional Preparedness, } \\
\text { Response and Co-operation in Combating Oil } \\
\text { Pollution Incidents ("Aktau Protocol") }\end{array}$ & Aktau & Kazakhstan & August 2011 & all Parties \\
\hline $\mathrm{CoP} 4$ & $\begin{array}{l}\text { The Protocol for the Protection of the Caspian Sea } \\
\text { against Pollution from Land-based Sources and } \\
\text { Activities ("Moscow Protocol") }\end{array}$ & Moscow & Russia & December 2012 & $\begin{array}{c}\text { Azerbaijan, Iran and } \\
\text { Turkmenistan }\end{array}$ \\
\hline CoP 5 & $\begin{array}{l}\text { The Protocol for the Conservation of Biological } \\
\text { Diversity ("Ashgabat Protocol") }\end{array}$ & Ashgabat & Turkmenistan & May 2014 & Turkmenistan \\
\hline $\mathrm{ECoP}^{*}$ & $\begin{array}{l}\text { The Protocol on Environmental Impact Assessment in } \\
\text { a Transboundary Context }\end{array}$ & Moscow & Russia & July 2018 & Azerbaijan \\
\hline
\end{tabular}

${ }^{\star}$ Extraordinary meeting the conference of the parties.

pollution of the Caspian Sea, however, the precise commitments or responsibilities were not written there. In addition, it was difficult for the Conference of the Parties (CoP) to the Tehran Convention to work on the future protocols of solving problems in the Caspian, as most IMO protocols and conventions, which could be used as an example, apply only to lands that have access to the world ocean.

The "Aktau Protocol" Concerning Regional Preparedness, Response, and Cooperation in Combating Oil Pollution Incidents became the first and only ratified protocol of all the Caspian countries, and it was fully entered into force on July 25, 2016. This is a paradox, because the struggle for oil reserves was the main bottleneck in order to achieve legal status as quickly as possible. As of January 2020 , the number of protocols has reached four. Unfortunately, three other protocols were not either signed or ratified by all parties. However, the situation might change soon, because "on August 12, 2018, the leaders of Azerbaijan, Iran, Kazakhstan, Russia and Turkmenistan signed the Convention on the Legal Status of the Caspian Sea" (Whitney, 2018).

\section{Concluding Marks}

If the Caspian basin were considered a high sea in the plenary session of the Fifth Caspian Summit, it would be divided according to UNCLOS regulation, and IMO's conventions such as BWM and MARPOL could enter into the force. However, international conventions sometimes change in connection with annual sessions at which some new details are discussed and taken into account. This should be clear to the Caspian community, because if they decide to follow international conventions, they should be ready for correction when new details appear. The Caspian is a unique landlocked reservoir that cannot be flexible in modifying the new regulations, thus, the officials of littoral states decided that the Caspian is neither a lake nor a sea and they issued special regulations need to be followed in the Caspian waters (Figure 3). 


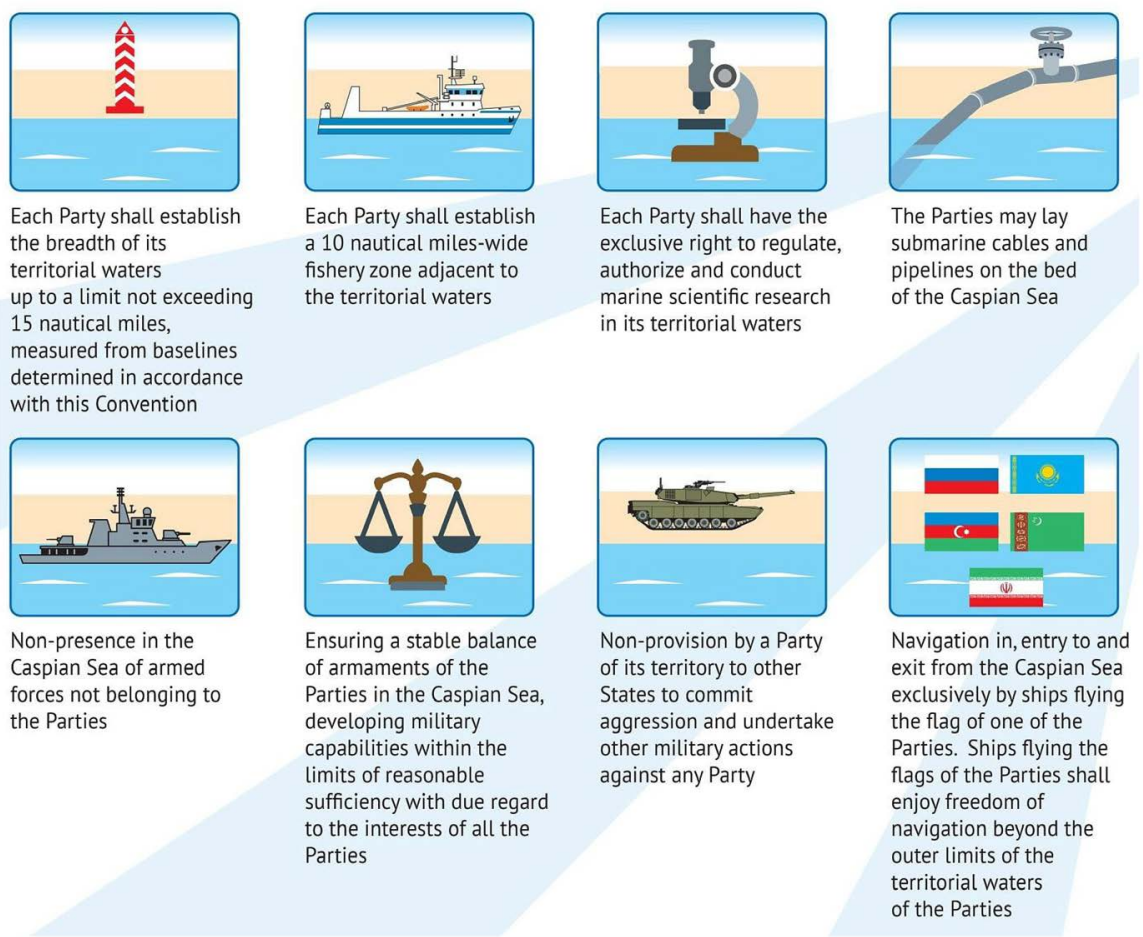

Figure 3. Provisions of the convention on the legal Status of the Caspian sea (Source: Valdai Club Foundation, 2018).

In the end, the authors are of the opinion when international conventions might not enter into the force anymore, the Caspian littoral states will totally focus on the "Tehran Convention", especially its non-ratified Protocols:

- The "Moscow Protocol" somehow touches the sewage issue over the Caspian Sea. It says that Parties needs to take into account the elements such as waste management, which cover the sewage sludge disposal but from the land-based sources. Secondly, the protocol does not have strict rules, such as the percentage of wastewater sludge allowed for discharge.

- The "Ashgabat Protocol" covers the protection, preservation and restoration of the health and integrity of the biological diversity and ecosystem of the unique Caspian Sea. However, an action plan must be prepared.

The amount of fleet is rising in Caspian countries due to the developing of the oil industry in the Caspian Sea, especially in Kazakhstan (40 ships in 2010) and consequently danger from this shipping is also increasing. When the legal status of the Caspian is already solved, the aforementioned Protocols need to be revised and then ratified.

\section{Authors' Contribution Statements}

All the authors have contributed equally to this paper. Altynbek Smailkhan supervised the project. Margulan Dairshenov wrote the manuscript and interviewed the representatives of the Kazakh national maritime shipping company "Kazmortransflot (KMTF)". Sarvar Khalikov and Mahdi Birafane collected the data, de- 
signed the project, provided critical feedback and didn't participate in the final evaluation of the manuscript.

\section{Acknowledgements}

This research was undertaken as a part of the two programs: graduate program in Transport Planning \& Management of Shanghai Maritime University; undergraduate program in Nautical Sciences of Kazakhstan Maritime Academy. The authors gratefully acknowledge the support from Alco E. Weeke, senior lecturer of STC Group, for review.

\section{Conflicts of Interest}

The authors declare no conflicts of interest regarding the publication of this paper.

\section{References}

Ballast Water Conference (2004). International Convention for the Control and Management of Ships' Ballast Water and Sediments, 2004.

Chesterman, S., Owada, H., \& Saul, B. (2019). The Oxford Handbook of International Law in Asia and the Pacific. Oxford: Oxford University Press. https://doi.org/10.1093/law/9780198793854.001.0001

De Blauwe, H. (2010). Mnemiopsis leidyi. World Register of Marine Species. http://www.marinespecies.org/aphia.php?p=image\&tid=106401\&pic=29437

Fonseca de Souza Rolim, M. H. (2009). The International Law on Ballast Water. Leiden: Brill. https://doi.org/10.1163/ej.9789004166523.i-402

Harkonen, T., Harding, K. C., Wilson, S., Baimukanov, M., Dmitrieva, L., Svensson, C. J., \& Goodman, S. J. (2012). Collapse of a Marine Mammal Species Driven by Human Impacts. PLoS ONE, 7, e43130. https://doi.org/10.1371/journal.pone.0043130

Ivanov, V. P., Kamakin, A. M., Ushivtzev, V. B., Shiganova, T., Zhukova, O., Aladin, N., Wilson, S. I., Harbison, G. R., \& Dumont, H. (2000). Invasion of the Caspian Sea by the Comb Jellyfish Mnemiopsis leidyi (Ctenophora). Biological Invasions, 2, 255-258. https://doi.org/10.1023/A:1010098624728

Julian, M. (2000). MARPOL 73/78: The International Convention for the Prevention of Pollution from Ships. Maritime Studies, 2000, 16-23. https://doi.org/10.1080/07266472.2000.10878605

Kamakin, A. M., Khodorevskaya, R. P., \& Paritckij, Y. A. (2018). Influence of Invader Ctenophoran Mnemiopsis leidyi (A. Agassis, 1865) on the General Parts of the Caspian Sea Ecosystem. Vestnik of Astrakhan State Technical University. Series: Fishing Industry, 1, 35-48. https://doi.org/10.24143/2073-5529-2018-1-35-48

Khalikov, S., Smailkhan, A., \& Nukuyeva, K. (2020). How Can Environmental Pollution by Ships Be Minimized at the New Terminal of Cargo Offloading Facility of the Caspian Sea? Journal of Geoscience and Environment Protection, 8, 28-45. https://doi.org/10.4236/gep.2020.81003

Kremer, P. (1979). Predation by the Ctenophore Mnemiopsis leidyi in Narragansett Bay, Rhode Island. Estuaries, 2, 97-105. https://doi.org/10.2307/1351633

Nasirov, E. (2010). The Contract of the Century. Vision of Azerbaijan. http://www.visions.az/en/news/206/1ee04b7e 
Patton, J. (2006). Stop Ballast Water Invasions Brochure and Poster. West Coast Ballast Outreach Project.

https://caseagrant.ucsd.edu/publication/stop-ballast-water-invasions-brochure-and-po $\underline{\text { ster }}$

U.S. Environmental Protection Agency (2019). Invasive Species in the Great Lakes. https://www.epa.gov/greatlakes/invasive-species-great-lakes

Valdai Club Foundation (2018). Convention on the Legal Status of the Caspian Sea. https://valdaiclub.com/multimedia/infographics/convention-on-the-legal-status-of-the -caspian-sea

Whitney, C. (2018). The Convention on the Legal Status of the Caspian Sea-A Sea or Not a Sea: That Is Still the Question. Norton Rose Fulbright.

https://www.nortonrosefulbright.com/en/knowledge/publications/5f222b95/the-conventi on-on-the-legal-status-of-the-caspian-sea---a-sea-or-not-a-sea-that-is-still-the-question

Yang, M., Liu, J., Zhang, X., \& Richardson, S. D. (2015). Comparative Toxicity of Chlorinated Saline and Freshwater Wastewater Effluents to Marine Organisms. Environmental Science \& Technology, 49, 14475-14483. https://doi.org/10.1021/acs.est.5b03796

Zimnitskaya, H., \& von Geldern, J. (2011). Is the Caspian Sea a Sea; and Why Does It Matter? Journal of Eurasian Studies, 2, 1-14.

https://doi.org/10.1016/j.euras.2010.10.009 